\title{
MICROBIAL LOAD IN THE LINE COMMON CARP REARING WATER FED DIFFERENT LEVELS OF DRY YEAST
}

(Received: 28.8.2012)

\author{
BY \\ N. M. Abdulrahman, Z. Kh. Khidhir and H. O. Murad* \\ Department of Animal Production,Faculty of Agricultural Sciences, and \\ *College of Veterinary Medicine, University of Sulaimani,Iraq
}

\begin{abstract}
This study was conducted at the Fish Laboratory,Animal Production Department, College of Agriculture, University of Sulaimani using commercial dry yeast at four levels (zero, 3, 5 and $7 \%$ ) to study their effects on the microbial load in fish aquaria water,total weight gain (g), daily growth rate $(\mathrm{g}$ /day) and relative growth rate(\%)as well as the $\mathrm{pH}$ of aquaria water.The experiment included four treatments, each in three replicates (plastic aquaria) in which 10 finger lings of common carp of the same weight (3.5 gram) were stocked in each aquarium. The actual duration of experimental feeding trial was three months. The results showed that $7 \%$ of dietary yeast gave the best result of total weight gain, daily growth rate, and relative growth rate. Moreover, it had the lowest microbial load which decreased from $6.2^{*} 10^{5}$ to $3.15^{*} 10^{4}$ at the end of the experiment as compared to the control without dry yeast that increased from $2.01 * 10^{3}$ to $5.4^{*} 10^{3}$. No significant differences were observed among the treatments in total weight gain $(\mathrm{g})$, daily weight gain ( $\mathrm{g} /$ day) and relative growth rate $(\%)$. The $\mathrm{pH}$ value ranged from 6.8 in the control treatment to 7.4 in the second treatment (5\% yeast). Accordingly, dry yeast could be used safely in feeding common carp up to $7 \%$ to attain the best microbial load.
\end{abstract}

Key words: carp, dry yeast, microbial load, relative growth weight, total daily growth rate, weight gain

\section{INTRODUCTION}

Probiotics can be defined as live microbial feed supplement that beneficially affect the host animal by improving its intestinal balance (Fuller, 1989). Most studies on the effects of probiotics on cultured aquatic animals have emphasized a reduction in mortality or the improved resistance against putative pathogens (Denev et al., 2009; Irianto and Austin, 2002). However, the beneficial effects are sometimes temporal, depending on the time of exposure (Balcázar et al., 2006; Verschuere et al., 2000).

In the last decade, the scientific community carefully examined the roles and effects of probiotics in aquaculture as an alternative to antimicrobial drugs, demonstrating positive effects on fish survival (Denev et al., 2009), growth (Burr et al., 2005), stress resistance, immune system enhancement and finally general welfare (Balcázar et al., 2006; Denev et al., 2009).

Microbial quality of farmed fish is largely determined by the quality of the water in which they were cultivated (Buras,1993; APHA, 1998; Balcázar et al., 2006 and Fafioye, 2011).Fish dependency on water is crucial. Hence the source, volume and the quality of physico-chemical parameters such as dissolved oxygen, total hardness, $\mathrm{pH}$, alkalinity, carbonate, nitrate, and temperature are the major factors to consider in relation to fish health. This brings about revelation on the influence of bacterial load and types of genera in water bodies (Denev,2008; Liu et al., 1992). Similarly, aquafeeds fed to cultured fish have been reported to have a considerable impact on the load of bacteria (Guo et al.,1988 and Azad et al., 1997).

The relationship between bacteria and the environment has received the attention of researchers (Fang et al., 1989; Fuller, 1989). However, the studies undertaken have been mostly limited to the relationship among aerobic heterotrophic bacteria and not all bacteria in the environment. Therefore, this study was designed to:

(i) Estimate the level of bacteria abundance in each aquarium.

(ii) Estimate $\mathrm{pH}$ variations among treatments.

\section{MATERIALS AND METHODS}

The experiment was conducted for 12 weeks, 
using common carp (Cyprinus carpio, $3.5 \mathrm{~g}$ average weight) finger lings obtained from Dukan hatchery. The experimental system included $100 \mathrm{~L}$ plastic tanks, each represents a replicate. Water samples were collected twice per month with separate sterile plastic containers, which were transferred to the laboratory for the microbial study.

Aseptically, $25 \pm 0.1 \mathrm{~g}$ of the sample were weighed, transferred into a sterile blender jar, then $225 \mathrm{ml}$ sterile phosphate buffer were added and blended at high speed for two minutes. This became the 1:10 dilution. The foam was permitted to settle, and then $10 \mathrm{ml}$ of the blended 1:10 dilution were pipetted into a $90 \mathrm{ml}$ dilution blank to make 1:100 dilutions. The procedure was repeated to prepare serial dilutions of $10^{-3}, 10^{-4}$, etc. All dilutions were shaken 25 times in a onefoot arc.

The dilutions were prepared before use according to the procedure of APHA (1998). About $1 \mathrm{ml}$ from the $10^{-1}, 10^{-2}, 10^{-3}, 10^{-4}$ etc., then the melted plate count agar was used (Biolife, Italy). After culturing, the plates were incubated at $35{ }^{\circ} \mathrm{C}$ (Memmert, Germany) for $48 \mathrm{hrs}$. For calculation, the dilution reverse was multiplied by the average count of double plate. A colony counter (W.T.W.BZG30, Korea) was used to count colonies on the duplicate plates.

The tested commercial dry yeast probiotics (Saccharomyces cerevisiae) were used to study their effects on growth performance of common carp (Cyprinus carpio finger lings. The animals were allowed to adapt to the experimental system for a week and fed with a conventional diet, contained 30\% crude protein and 2880 kilocalori energy. There after the different treatments (the control treatment without dry yeast, 3\% dry yeast, $5 \%$ and $7 \%$ dry yeast) were randomly assigned to the tanks with three replicates per treatment. Feed was manually administered adlibitum 2 times a day for 12 weeks. A daily record was kept of feed offered. Bulk weight of the cultured fish in each aquarium was measured weekly to calculate growth in weight. The experimental diets used in the study represent the standard diet found in local markets.

All data were analyzed by a one-way ANOVA using a Statistical Analysis software Program of SPSS (XLSTAT-PRO 7.5). The Duncan's Multiple Range Test was used to determine the differences between the treatment means. The results were considered statistically significant at the level of $\mathrm{P}<0.05$ (Duncan, 1955).
The weight gains (\%), RGR were evaluated based on the standard formula as follows as mentioned in (Jafaryan et al., 2011):

$\mathrm{WG}=\mathrm{W}_{1}-\mathrm{W}_{0}$ Where:WG $=$ Average weight gain $(\mathrm{g})$

$\mathrm{W}_{1}=$ Average final weight $(\mathrm{g})$

$\mathrm{W}_{0}=$ Average initial weight $(\mathrm{g})$

Daily weight gain $=\left(\mathrm{W}_{1}-\mathrm{W}_{\mathrm{o}}\right) \div \mathrm{T}$

Relative growth rate $(\%)=$

$$
\left[\left(\mathrm{W}_{1}-\mathrm{W}_{0}\right) \div \mathrm{W}_{0}\right] \times 100 \text {. }
$$

Where, $\mathrm{W}_{0}=$ Initial body weight $(\mathrm{g}), \mathrm{W}_{1}=$ Final bodyweight (g) and $\mathrm{T}=$ Time (day)

\section{RESULTS AND DISCUSSION}

The bacterial loads in water are shown in Table (1). The total bacterial load varied from $2.01 * 10^{3}$ to $5.4 * 10^{3} \mathrm{cfu} \mathrm{ml}{ }^{-1}$ in the control, and from $2.63 * 10^{3}$ to $3.0^{*} 10^{4}$ in the first treatment ( $3 \%$ dry yeast). With increasing yeast level, the total bacterial load changed from $4.8 * 10^{4}$ to $3.65 * 10^{3}$, and from $6.2 * 10^{5}$ to $3.15 * 10^{4}$ in the second and third treatments, respectively.The results showed pronounced variations in total bacterial load of aquarium water over time.

The bacterial load in the samples was the highest in August. This may have resulted from the high water temperature $\left(32^{\circ} \mathrm{C}\right)$. While, low temperature $\left(15^{\circ} \mathrm{C}\right)$ may be the major factor in decreasing bacterial loads in the pond water. It was reported that bacterial load might be increased with an increase in water temperature (Al-Salim et al., 2009;APHA, 1998).

Table (1): Microbial load in aquarium water

\begin{tabular}{|l|l|l|l|l|}
\hline Sampling & Control & $\begin{array}{c}\text { T1(3\% } \\
\text { DY) }\end{array}$ & $\begin{array}{c}\text { T2(5\% } \\
\text { DY) }\end{array}$ & $\begin{array}{c}\text { T3(7\% } \\
\text { DY) }\end{array}$ \\
\hline Time 1 & $2.01 * 10^{3}$ & $2.63 * 10^{3}$ & $4.8 * 10^{4}$ & $6.2 * 10^{5}$ \\
\hline Time 2 & $5.65 * 10^{2}$ & $1.505 * 10^{4}$ & $9.6 * 10^{5}$ & $4.15 * 10^{3}$ \\
\hline Time 3 & $4.25 * 10^{1}$ & $3.3 * 10^{3}$ & $4.4 * 10^{3}$ & $1.1 * 10^{4}$ \\
\hline Time 4 & $5.4 * 10^{3}$ & $3.0^{*} 10^{4}$ & $3.65 * 10^{3}$ & $3.15^{*} 10^{4}$ \\
\hline
\end{tabular}

DY: dry yeast: Time 1 at $17^{\text {th }}$ august;Time $29^{\text {th }}$ august; Time 3 at $6^{\text {th }}$ September; Time 4 at $29^{\text {th }}$ September.

The data illustrated in Table (2) show that $7 \%$ yeast treatment was more effective in enhancement of body weight of common carp Cyprinus carpio. These results are in agreement with the findings of Ozório et al. (2012) who found that $10 \%$ brewer's yeast were the optimal level, where more than this level (20 and 30\%) performed worse as regards to body weight. Different workers (Allam,2007; Mohapatra et al., 2012; Pooramini et al., 2009; and Tewary and Patra, 2011) reported similar positive effects of dietary Pronifer, algae, and yeast on the average body weight gain of tilapia fish. 
Table (2): The effect of dry yeast levels on the growth performance of common carp fingerlings:

\begin{tabular}{|c|c|c|c|}
\hline $\begin{array}{c}\text { Dry yeast } \\
(\boldsymbol{\%})\end{array}$ & \multicolumn{3}{|c|}{ Characteristics } \\
\cline { 2 - 4 } Zero & $12.32 \pm 0.0 \mathrm{a}$ & $0.15 \pm 0.0 \mathrm{a}$ & $353.01 \pm 0.0 \mathrm{a}$ \\
\hline $\mathbf{3}$ & $9.37 \pm 2.22 \mathrm{a}$ & $0.12 \pm 0.03 \mathrm{a}$ & $286.73 \pm 24.14 \mathrm{a}$ \\
\hline $\mathbf{5}$ & $7.39 \pm 2.59 \mathrm{a}$ & $0.09 \pm 0.03 \mathrm{a}$ & $249.17 \pm 79.27 \mathrm{a}$ \\
\hline $\mathbf{7}$ & $11.20 \pm 1.06 \mathrm{a}$ & $0.13 \pm 0.01 \mathrm{a}$ & $318.94 \pm 40.39 \mathrm{a}$ \\
\hline
\end{tabular}

All the probiotic-supplemented diets resulted in higher growth than that of the control diets, suggesting that the addition of the probiotics mitigated the effects of the stress factors. This resulted in better fish performance, with better growth results in the diets supplemented with the dry yeast (Iranshahi et al., 2011; Lara-Flores et al., 2003). Further more, it was reported that the inclusion of yeast in the diet improves feed efficiency, organic phosphorus (phytic acid) utilization, and fiber digestion (Al-Salim et al., 2009, Jafaryan et al., 2011; Tewary and Patra, 2011). In this respect, Noh et al. (1994) studied the effect of supplementing yeast ( $S$. cerevisiae) and bacteria (Streptococcus faecium) in the diet of Israeli carp and reported the better growth response of fish fed probioticsupplemented diets than that of the diet without probiotic supplementation.

Many published reports demonstrated positive effects of probiotics and prebiotics in feeds for various fish species, including common carp (Cyprinus carpio) (Denev,2008; Randall,1991;Staykov et al., 2005a,b, and c, d;Staykov et al.,2006a,b,c;Staykov et al., 2007a,b; Yanbo and Zirong, 2006).

However, the obtained results could be explained by some factors as dietary yeast improved growth performance due to yeast is a source of protein (De Silva, 1989). Yeast acts as a source of enzymes, i.e. amylase, protease and lipase that may improve food digestion and consequently food utilization. Moreover, yeast is a very good source of vitamin B6 $(39.8 \mathrm{mg} / \mathrm{kg}$ dry matter) as reported by Mc Dowell (1989). Vitamin B6 may act as a stimulator of growth hormone (Allam, 2007).

In fish culture, water $\mathrm{pH}$ is lowered by $\mathrm{CO}_{2}$ produced from the respiration of fish and bacteria. Metabolism, and $\mathrm{CO}_{2}$ production, increase as fish grow in the system (Attramadal, 2011). Abd El-Halim et al. (1989) found that the addition of living yeast in diet improved the performance of $O$. niloticus. Also, Scholz et al.
(1999) reported that $S$. cerevisiae improved the growth and survival of sea bass fry. They attributed this action to adherence of $S$. cerevisiae cells to the gut and the secretion of amylase enzymes, which share in increased digestibility of the diet. On the other hand, the increased growth performance of O.niloticus treated with commercial products (Megalo and Diamond-V yeast, containing living $S$. cerevisiae with $B$. subtilis and dead $S$. cerevisiae, respectively) could be also attributed to the inhibition of some intestinal bacterial flora and increasing the nonspecific immunity of the treated O.niloticus. The adherence capacity of $S$. cerevisiae and B. subtilis to the intestinal mucosa inhibits the attachment of the other intestinal bacteria to these binding sites and so preventing the disease occurrence with its negative impact on fish growth ( Marzouk et al., 2008).

The values of $\mathrm{pH}$ are within the ranges recommended for warm water fish cultured $\mathrm{pH}$ of $6.8 \pm 0.2$ ) which falls within the 5-9 range given by (Staykov et al., 2007 a \&b) and with that of Abdulrahman and Muhammad, (2012), though the average $\mathrm{pH}$ taken from the aquaria gave 6.8; it was still desirable for fish production as shown in Table (3). The desirable range for pond $\mathrm{pH}$ is 7.97- 8.06 and the acceptable range is 5.5 10.0(DWAMD, 1994). The present results are in agreement with(El-Nemaki et al., 2008).

In conclusion, the adding of $7 \%$ dietary yeast gave the best result of the total weight gain, growth rate and it had the lowest microbial load. Therefore, we recommend adding 7\% dietary yeast for obtaining the best microbial load in common carp water.

Table (3): The effect of yeast addition on aquaria water $\mathrm{pH}$.

\begin{tabular}{|c|c|}
\hline Dry yeast (\%) & $\mathbf{p H}$ \\
\hline Zero & $6.55 \mathrm{a}$ \\
\hline $\mathbf{3}$ & $6.85 \mathrm{a}$ \\
\hline $\mathbf{5}$ & $7.2 \mathrm{a}$ \\
\hline $\mathbf{7}$ & $6.9 \mathrm{a}$ \\
\hline
\end{tabular}




\section{REFERENCES}

Abd El-Halim A., Nour A., Omar E. and Abd ElLatif M. G. (1989). Effect of different levels of active or inactive yeast on growth performance and feed utilization of Nile tilapia,Oreochromis niloticus. $2^{\text {nd }}$ Alex, Conf.fd. Sci. Tech., pp. 396-405.

Abdulrahman N.M. and Muhammad D.A. (2012). The effect of dry yeast levels on some water parameters. The Iraqi J. Vet. Med. 36(1):107-119.

Allam H. Y. H. (2007). Physiological effects of some additives on growth, blood constituents and immunity in Nile tilapia (Oreochromis niloticus). Ph.D. Thesis, Animal and Poultry Production Department, Faculty of Agriculture, Assiut University:247.

Al-Salim N. K., Khamees N. R. and Al-Niaeem K.S.(2009).Intestinal Bacteria in the University of Basrah fish ponds, Iraq. J. of Al-Anbar University for Pure Science: Vol.3: No.1.

APHA (1998). American Public Health Association: Standard methods for the examination of water and wastewater, $20^{\text {th }}$ edn. APHA, Washington, DC, USA.

Attramadal K. J. K. (2011). Water treatment as anapproach to increase microbial control in the culture of cold water marine larvae. Ph.D.Thesis, Norwegian University of Science and Technology, Faculty of Natural Sciences and Technology Department of Biology: 177.

Azad I.S., Shankar K.M. and Mohan C.V.(1997). Evaluation of Aeromonashydrophila for oral vaccination of Carp. In T. W. Flagel and I. H Macrae (eds.), Disease in Asian Aquaculture III Fish Health Section, Asian Fisheries Society, Manila, pp. 181-185.

Balcázar J.L., De Blas I., Ruiz-Zazuela I. Cunningham D. Vandrell and D. Muzquiz JL.(2006).The role of probiotics in aquaculture. Veterinary Microbio 114: 173-186.

Buras N.L. (1993). Microbiological aspects of fish grown in treated waste water. Water Res., 21(10): 1-10.

Burr G.,Gatlin D. and Ricke S.(2005). Microbial ecology of the gastrointestinal tract of fish and the potential application of prebiotics and probiotics in fin fish aquaculture. J. World Aquacul. Soc. 36(4): 425-436.

Denev S.A. (2008). Ecological Alternatives of Antibiotic Growth Promoters in the Animal Husbandry and Aquaculture. D.Sc.Thesis, Department of Biochemistry Microbiology, Trakia University, Stara Zagora, Bulgaria, pp
294.

Denev S., Staykov Y., Moutafchieva R. and Beev G.(2009). Microbial ecology of the gastrointestinal tract of fish and the potential application of probiotics and prebiotics in finfish aquaculture. , IAU, Tonekabon, IAR09-1011.

De Silva S. S., Gunasekora R. M. and Atapattu D. (1989). The dietary protein requirement of young tilapia and an evaluation often least cost dietary protein levels. Aquaculture, 80:271-284.

Duncan D. B. (1955). Multiple range and multiple F test. Biometrics 11:1-42.

DWAMD, (1994). Division of Water Ambient Monitoring Database. Ehiagbonare, J.E, Adjarhore, R.Y. and Enabulele,S.A.(2009). Effect of Cassava effluents on Okada natural water. Afr J Biotech . 8(2): 2816-2818.

El-Nemaki F.A,Ali N. A., Zeinhom M. M. and Radwan O. A.(2008). Impacts of different water resources on the ecological parameters and the quality of Tilapia production at elAbbass fish farms in Egypt. $8^{\text {th }}$ International Symposium on Tilapia in Aquaculture .

Fafioye O. O.(2011). Preliminary studies on water characteristics and bacterial population in high yield Kajola fish ponds. J.of Agricultural Extension and Rural Development. 3(3): 6871

Fang X., Guo X. and Wang J.(1989). The preliminary studies on the enzymes, yeast culture and probiotics on growth performance of Israeli carp. Kor. J. Anim. Sci., 36, 480-486.

Fuller R.(1989). Probiotics in man and animals. J. Appl. Bacteriology 66: 365-378.

Guo X., Fang Y. and Wang J.(1988). The preliminary studies on the heterotrophic bacteria in high yield Fishponds. Fish. J., 13(2): 101-109.

Iranshahi F., Faramarzi M., Kiaalvandi S. and Lashkar Boloki M. (2011). The Enhancement of Growth and Feeding Performance of Persian Sturgeon (Acipenser persicus) Larvae by Artemia urmiana Nauplii Bioencapsulated via Baker's Yeast (Saccharomyces cerevisiae). J. of Animal and Veterinary Advances. Vol: 10 (20) : 2730-2735.

Irianto A. and Austin B. (2002). Probiotics in Aquaculture. J Feed Diseases 25: 1-10.

Jafaryan H., Taati M. M. and Jafarzadeh $M$. (2011). The enhancement of growth parameters in common carp (Cyprinus carpio) larvae using probiotic in rearing tanks and feeding by 
various Artemia nauplii. AACL Bioflux. 4(4):511-518.

Lara-Flores M., Olvera-Novoa M., GuzmánMe'ndez B.E. and Lo'pez-Madrid W. (2003). Use of the bacteria Streptococcus faecium and Lactobacillus acidophilus, and the yeast Saccharomyces cerevisiae as growth promoters in Nile tilapia (Oreochromis niloticus). Aquaculture 216: 193-201.

Liu G., Bao W. and Liu Z.(1992). Preliminary studies on the bacteria in pond mud. J. Fish Biol., 16(3): 248-286.

Marzouk M. S., Moustafa M. M. and Mohamed N. M. (2008). The influence of some probiotics on the growth performance and intestinal microbial flora of $O$. niloticus. $8^{\text {th }}$ International Symposium on Tilapia in Aquaculture 2008: 1059- 1071.

Mc Dowell L. R. (1989). Vitamins in Animal Nutrition. Comparative Aspects to Human Nutrition, pp. 245, Academic Press.

Mohapatra S., Chakraborty T., Prusty A. K., Das P., Paniprasad K. and Mohanta K. N.(2012). Use of different microbial probiotic in the diet of roho, Labeo rohita fingerlings; effects on growth, nutrient digestability, and retention, digestive enzyme activities and intestinal microflora. Aquaculture Nutrition. 18; 1-11.

Noh H., Han K.I., Won T.H. and Choi Y.J.(1994). Effect of antibiotics,enzymes, yeast culture and probiotics on growth performance of Israeli carp. Kor. J. Anim. Sci., 36, 480-486.

Ozório R.O. A., Portz L., Borghesi R. and Cyrino J.E.P. (2012). Effects of Dietary Yeast (Saccharomyces cerevisia) Supplementation in Practical Diets of Tilapia (Oreochromis niloticus). Animals, 2, 16-24.

Pooramini M., Kamali A., Hajimoradloo A., Alizadeh M. and Ghorbani R. (2009). Effect of using yeast (Saccharomyces cerevisiae) as probiotic on growth parameters, survival and carcass quality in rainbow trout Oncorhynchus mykiss fry. Int.Aquat. Res. 1: 39-44.

Randall D. (1991). The Impact of variation in water $\mathrm{pH}$ on fish.Aquaculture and Water Quality, Brune D.E and J. R. Tomasso, eds Baton Kouge, LA: World Aquaculture Society. : 79-103.

Scholz U., G. GarciaDiaz D. Ricque L. E. Cruz Suarez E. Vargas Albores and Latchford J. (1999). Enhancement of Vibriosis resistance in juvenile Penaeus vannamei by supplementation of diets with different yeast products. Aquaculture 176,271-283.
Staykov Y., Denev S.A. and Spring P.(2005a). The Effect of Dietary Mannan oligosa charides (Bio-Mos ${ }^{\circledR}$ ) on the Growth Rate and Immune Function of Rainbow Trout (Salmo Gairdneri Irideus G.) Growth in Netcages. In: Lessons From The Past To Optimise The Future Aquaculture Europe 2005 (Eds B. Howell and R. Flos), August 5-9 ${ }^{\text {th }}$, Tronheim, Norway, European Aquaculture Society, Special Pub. No. 35, pp 427-428.

Staykov Y., Denev S.A. and Spring P.(2005b). The Effect of Dietary Mannan oligosaccharides (Bio-Mos ${ }^{\circledR}$ ) on the Growth Rate and Immunity Status of Rainbow Trout (Salmo Gairdneri Irideus G.) Grown in Raceways. In: Lessons From The Past To Optimise The Future Aquaculture Europe 2005 (Eds B. Howell and R. Flos), August 5-9th, Tronheim, Norway, European Aquaculture Society, Special Pub No 35, pp 429-430.

Staykov Y., Denev S.A. and Spring P.(2005c). The Influence of Dietary (Bio-Mos ${ }^{\circledR}$ ) on the Growth Rate and Immune Function of Common Carp (Cyprinus Carpio L.). In: Lessons From The Past To Optimise The Future - Aquaculture Europe 2005 (Eds. B. Howell and R. Flos), August 5-9 ${ }^{\text {th }}$, Tronheim, Norway, European Aquaculture Society, Special Pub. No. 35: 431-432.

Staykov Y., Spring P. and Denev S.A.(2005d). Influence of dietary Bio-Mos ${ }^{\circledR}$ on growth, survival and immune status of rainbow trout (Salmo gairdneriirideus G.) and common carp (Cyprinus carpio L.). In : Nutritional Biotechnology in the Feed and Food Industries. (Eds. T.P. Lyons, and K. Jackues). Nottingham University Press, Nottingham, UK. pp 333343.

Staykov Y., Spring P. and Denev S.A. (2006a). Influence of dietary Bio-Mos ${ }^{\circledR}$ on the growth rate and immune function of Rainbow trout (Salmo gairdneri irideus G.). Proceedings of Aquaculture Meeting „Improving Stock Performance and Efficiency the Natural Way", $7^{\text {th }}$ November, Dunboyne, Ireland, pp 23.

Staykov Y., Spring P. and Denev S.A.(2006b). Influence of dietary Bio-Mos ${ }^{\circledR}$ on the growth rate and immune function of common carp (Cyprinus carpio L.). Proceedings of Aquaculture Meeting, Improving Stock Performance and Efficiency the Natural Way", $7^{\text {th }}$ November, Dunboyne, Ireland, pp 35 .

Staykov Y., Spring P. and Denev S.A. (2006c). 
Effects of dietary Bio-Mos®on the growth rate and immunity of rainbow trout (Salmo gairdneriirideus G.) grown in raceways. Proceedings of Aquaculture Meeting ,Improving Stock Performance and Efficiency the Natural Way", $7^{\text {th }}$ November, Dunboyne, Ireland: 21.

Staykov Y., Spring P., Denev S.A. and Sweetman J.(2007a). Effect of amannan oligosa ccharide on the growth performance and immune status of rainbow trout (Oncorhynchus mykiss). Aquacul Int .2: 153-161.

Staykov Y., Spring P., Sweetman J. and Denev S.A. (2007b). The influence of 2 and $4 \% \mathrm{Nu}-$ Pro ${ }^{\circledR}$ on the growth performance of Common carp (Cyprinus carpio L.), raised in net cages. Proceedings of the $22^{\text {nd }}$ Annual Symposium "Nutritional Biotechnology in the Feed and Food Industries" (Suppl. Abstracts of Poster
Presented), (Eds: T. P. Lyons and K. A. Jacques) April 23-26 ${ }^{\text {th }}$, 2007, Lexington, Kentucky, USA, pp. 84.

Tewary A. and Patra B.C. (2011). Oral administration of baker's yeast(Saccharomyces cerevisiae) acts as a growth promoter and immune modulator in Labeo rohita (Ham.). J. Aquac. Res. Development 2:109.

Verschuere L., Rombaut G., Sorgeloos P. and Verstraete W. (2000). Probiotic bacteria as biological control agents in aquaculture. Microbiology and Molecular Biol. Rev. 64: 655-671.

Yanbo W. and Zirong X. (2006). Effect of probiotics for common carp (Cyprinus carpio) based on growth performance and digestive enzyme activities. Animal Feed Sci. Technol. 127: 283-292.

$$
\begin{aligned}
& \text { الحمل الميكروبي لمياه تربية اسماك الكارب العادي المغذاة على مستويات مختلفة من الخميرة الجافة } \\
& \text { نسرين محي الدين عبدالرحمن - زيد خلف خضر - هازاو عمر مراد } \\
& \text { قسم الانتاج الحيو انى- كلية الزر اعة ـ * كلية الطب البيطرى- جامعة السليمانية - العراق }
\end{aligned}
$$

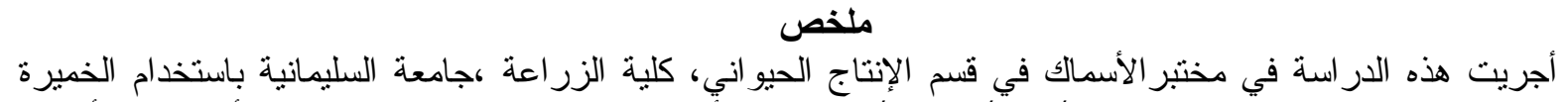

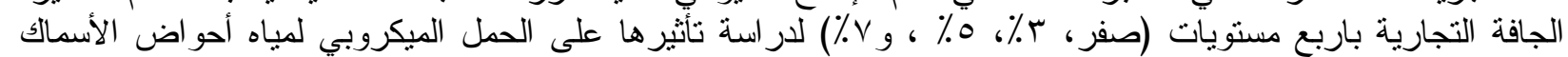

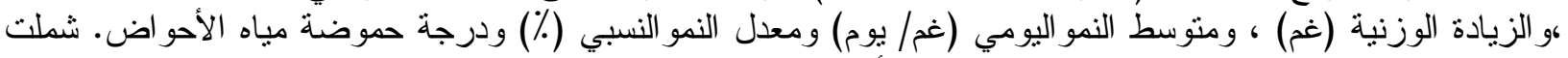

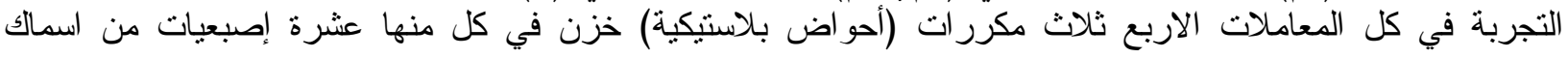

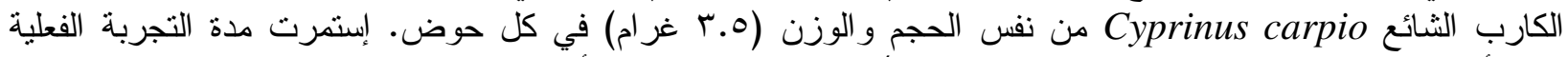

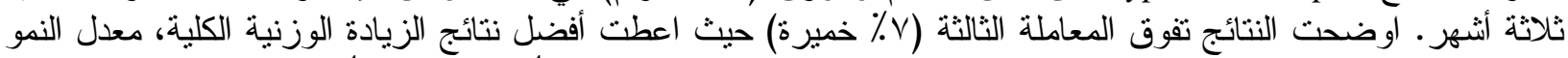

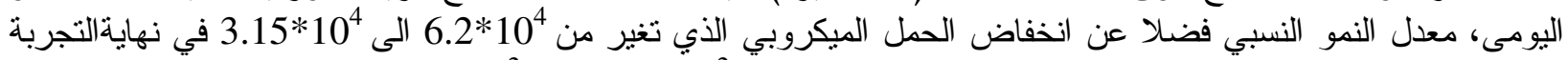

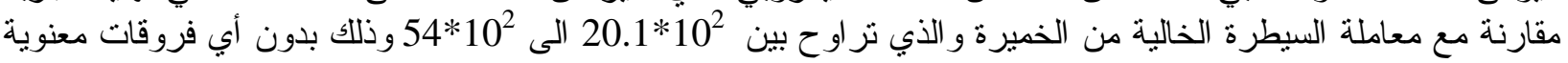

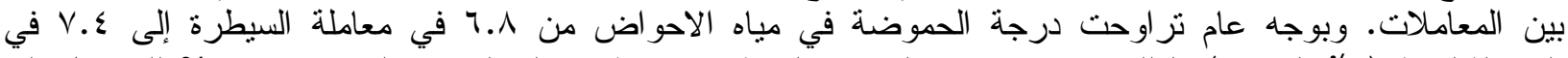

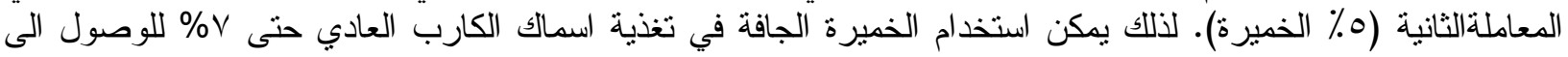
افضل حمل ميكروبي في المياه.

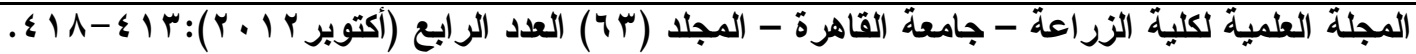

